Portland State University

PDXScholar

Dissertations and Theses

Dissertations and Theses

1975

\title{
A program to teach awareness of stress
}

Catherine Collins Lu

Portland State University

Follow this and additional works at: https://pdxscholar.library.pdx.edu/open_access_etds Let us know how access to this document benefits you.

\section{Recommended Citation}

Lu, Catherine Collins, "A program to teach awareness of stress" (1975). Dissertations and Theses. Paper 1178.

https://doi.org/10.15760/etd.1177

This Thesis is brought to you for free and open access. It has been accepted for inclusion in Dissertations and Theses by an authorized administrator of PDXScholar. Please contact us if we can make this document more accessible: pdxscholar@pdx.edu. 
A PROGRAN TO TEACH ANARENESS OF STRESS

by

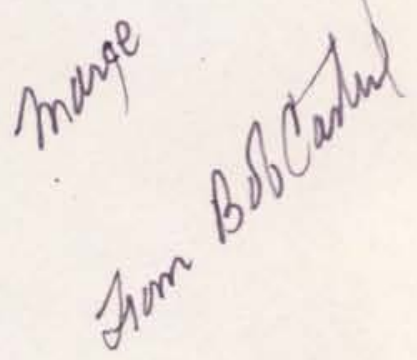

CATHERINE COLLINO LU

A substantial paper submitted in partial fulfillment of the requirertents for the degree of

MASTER OF SCIENCE

SPEECH: EMPHASIS SPEECH PATHOLOGY/AUDIOLOGY

Portland State University

1975 
APPROVAL PAGE

This substantial paper by CATHERINE COLLINS LU was presented on Varch 7, 1975 and was approved by

$$
\text { J oan MClahon }
$$




\section{ACKNO VLEDGPENTS}

The author wishes to express her indebtedness to Dr. Jares Maurer for his tire and effort in the developrental stages of this program. She also wishes to express her thanks and gratitude to Irs. Joan lclahon for her counselling, pertinent criticism and helpful suggestions. 
TABLE OF CONTENTS

PAGE

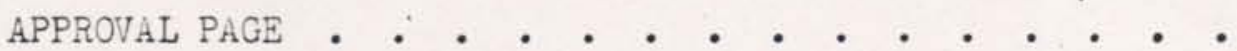

ACKNONLEDGLENTS • • • • • • • • • • • • •

GHAPTER

I INTRODUCTION • • • • • • • • • •

II A BRIEF DESCRIPTION UF HISTORICAL DEVELOPNENT AND TECHNIQUES IN TEACHING STRESS • • • • •

III STRUCTURE AND RATIONALE FOR THE PROGRAN • • •

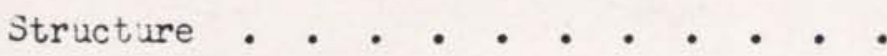

Rationale . . . . . . . . . 8

IV A PROCRAN TO REACH AMRENESS OF STRESS • • • • 10

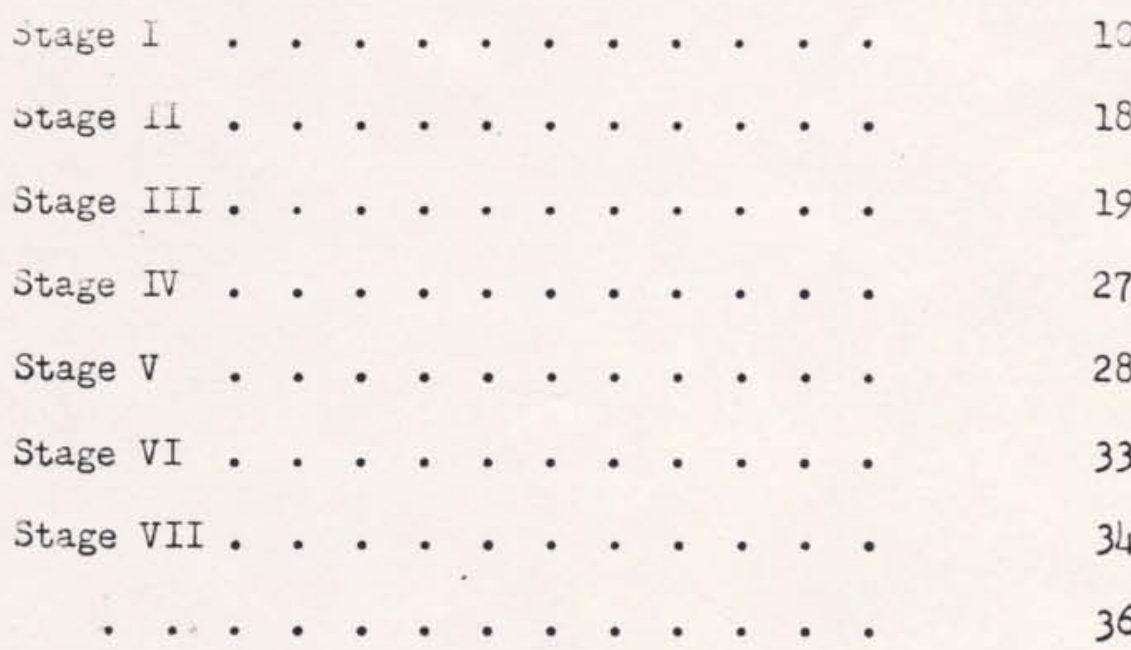

V SUMARY • . . • . . . . . . . 36

BIBLIOGRAPHY

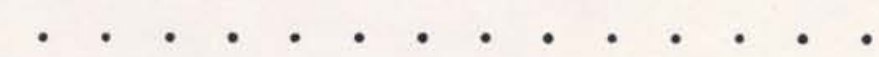


CHAPTER I

\section{INTRODUCTION}

As a project for a behavior modification class, an auditory training program of sentence stress instruction was desicned for the purpose of eliciting responses to sound from a hearing inpaired child. According to past experience, it was found that arplification alone was not sufficient to enable the child to use appropriate stress in connected speech; threfore, a drim beat, as an additional cue, paired with stressed syllables, was utilized. The current program is an outgrowth from a pilot study which will be briefly described as follows:

The subject of the pilot study was a seven year old hearing impaired child. Her audiograr. indicated that she had not responded to pure tones above $1000 \mathrm{~Hz}$. The first task was to nake the child aware of the presence or absence of sound and a drum was used for this purpose. She was to state if the drum had been hit or not, and if so, how many tires. She did not succeed in this task so another child was brought in as a model for vicarious learning. By watching the model, she quickly understood what responses were required and her responses becare consistent and accurate. Two sentences were introduced, both of which contained words of equal stress value. The drum was struck and was accompanied by the vocalization of one sentence. Her response was the statement of how many syllables were present in the sentence and an indication of which sentence had been presented by pointing to the correct one. The drum beat was faded and verbalization of the sentences was the only stimulus, when her 
responses were consistent and 80 percent accurate. Her responses rerained consistent and accurate until sentences of five syllables were presented and varied stress patterns becare an irportant factor. The results were nost encouraging but modifications were needed in the program. It was felt that by revising the program it would be more useful in helping hearing inpaired children to becore aware of stress in connected speech so they could eventually be able to use appropriate stress spontaneodsly in their own speech.

The purpose of this paper was to design a strategy for teaching stress to children with severe to profound hearing losses to progress from the simple detection of the presence or absence of a drum beat to the identification of the number of stressed syllables in spoken sentences with out the aid of the drum beat. Enphasis was focused upon the sirplicity of prograrming structure and minimum of equiprent. 


\section{A BRIEF DESCRIPTION OF HISTORICAL DEVELOPMENT AND TECHNIQUES IN TEACHING STRESS}

Auditory training for the hearing impaired child has changed greatly through the years due to the progress in amplification equipment and changing concepts in the teaching of this particular aspect to the hearing impaired child. In the past, it was believed that the most important aspect of speech was the production of the phonemes. However, it has been found that other factors such as duration of vowels and consonants, amount of breath, rate variation, incomplete mastery of time-based accentuation and monotonous speech patterns, negatively influence the intelligibility of the speech of the hearing, impaired individual (Calvert, 1952, and Jones, 1967). Jones (1967) stated:

Such attributes as characteristic monotone, lack of accent and rhythm, poor resonance and poor carrying power and unnatural qualities have been ascribed to "deaf voice."

Stress appears to have become increasingly important in recent literature on linguistics and speech. Pike (1945) stated that the organizing principle for rhythm and intonation was stress. Woodward (1967) said that speech patterns which are normally carried by inflection and stress are needed to relate particular linguistic meanings. Unfamiliarity with these patterns may adversely affect the intelligibility and comprehension.

Moulton (1970) said stress is very important in the English language because it is used extensively as part of the structure of words and sentences. Voodward (1967), Tash (1974) and Simmons- 
Nartin (1972) naintained that the English language was a tire-stress language, i.o., that stressed sjllables terded to jocur at regular intervals and tended to determine the basic rate of speech, and unstressed syllables were crowded into the basic rate. SimmonsVartin (1972) further siggested trat the perception of stress patterns colld help the child acquire a more natural rnythm in his speech and in his voice quality die to less tension of the vocal rechanisus.

In the literature, stress appears to have been a poorly defined component of prosody intil recently. Prior to then, tie literature dealt solely. with the analysis of acoustic characteristics of phoneres, descriptions of how they were formed and techniques and exercises for their instruction. Stress was referred to but rarely defined and when a definition was used, it was often given in connection with intonation, enphasis, accent or inflection. These definitions soretires conflicted with one another and tended to be confusing. The following are some of the definitions found in the literature:

Thomas (1947) defined stress as the relative increase in the force of utterance of a sound or syllable.

Aurbach, et al.(1963) stated that the three aspects of stress were loudness, duration and pitch. For instance, the stressed syllables were louder, their vowel sounds were longer and the pitch of the voice was higher.

Moulton (1970) stated that stress denoted those syllables which received relative prominence within a word or sentence. He continued to differentiate between word stress and sentence stress. He defined pitch separately but naintained that pitch and stress jointly played an important role in timing and rhythm of the English language. 
Lehman (1971) suggested that the supra-segnental phonenes (elements of prosody) were stress, pitch and juncture. She said the primary stressed syllable was the loudest syllable relative to the others. She also stated that every syllable in the English language was said with sone degree of stress, pitch and terminal juncture and that the meaning of a sentence was changed merely by changing the supra-segnental phoneres.

For the purpose of this paper, stress is neant to denote the prominence given to a syllable or a word by increasing the intensity.

Stress has been taught in various ways. The following are some exarples of methods which have been used.

Geary, et al.(1959) used a horizontal line under the word which received the stress in a phrase or sentence. She reconiended the use of poens, songs and oral reading of selections which had been appropriately marked for stress by the teacher.

Noodward (1967) and Tash (1974) suggested that stress should be taught by drills in wich syllables with various stress patterns were indicated for the child. A slash (/) used above stressed syllables appeared as "boo boo boo boo." After the child had mastered the syllabic stress task, they then used phrases and/or sentences which had the sa e stress pattern as that with the syllables, i.e., "Get the paper."

Once the child had learned the use of stress, the idea of intonation was initiated, i.e., "I think it's John's book," where the position of the line indicated the relative intonation of the words in the sentence.

Birkenshaw (1967) used musical instruments, particularly a drum, 
to teach stress. She said the rhythm of the sentences could be shown with a drum and stressed words or syllables could be indicated simply by beating the drum nore louily for them. She said that no mistake could arise concerning wich syllable was stressed.

Brick (1973) reconmended Exhythmics to teach stress. Eurhythmics as defined, is the "art of harmonious and expressive" body moverents. She naintained that Eurhythmics and audition rade the child more aware of the pleasurable aspects of sound. She said that to learn stress the children were taught to nove from a crouching position to an expansive one to indicate crescendo (increasing intensity) and moving back to a crouching position to indicate a decrescendo (decreasing intensity) while listening to a relody. She claired that stress and accent to a Eurhythmics teacher were instrumental in making a hearing impaired child's speech intelligible to hearing people, and that transfer did take place from rusical interpretation to the speech of the child. Nagner (1973) recorrended clapping out riythms with the children. She said that the procedure helped sore children itprove the rate of utterance, the duration of syllables, intensity and even pitch of unaccented syllables. She also used nonsense syllables to indicate stress patterns. Words, phrases and sentences were then used in these sane patterns. She said the children soon learned to fit their own words and phrases to the various patterns.

The Nulti-Sensory Speech Trainer (NSST) was developed to stimulate and develop speech sounds and patterns. Part of the system included a VU meter to be used for volume control and an oscilloscope for matching patterns. The amplification system, naturally, provided auditory stimulation. All three devices co.ld be used to teach stress. 
CHAPTER III

STRUCT RE AND FATIONALE FOR THE PROGRAM

\section{Structure}

The program is divided into seven stages and each stage is separated into tasks. At the beginning of each stage is a orief description of the stage and the behavioral objectives to be autained by the child. There are branching tasks to utilize in the event criterion is not met by he child. Sore stages are divided into two parts die to response changes expocted of the chili. Stage I, Part A, involves tne identification of sound presence and countin; tie nurier of beats present. It is for the rostpart a listening task. Part $b$ involves the repetition of a syllable pattern, so although it is a listening task it also becomes a verbal response task. The stinulus is a drunbeat. It is here that the drum is paired with a syllable for the first time. Cards are used as visual cues to aid the child in both parts of this stage.

Stage II, Part A, is a listening task in which the child is to identify the presence of sound and count the number of syllables. The stimulus changes from a drum beat to the voice. Part B is presented with the voice as the stimulus and a verbal response indicating the correct number of syllables is required.

Stage III, Part A, requires finer auditory discrinination of loud versus softer sounds. The child nust identify the number of . beats present and the stress patterns. The drum is the stimulus for this part and cards with the syllables written on them are used as 
visual cues. A slash rark (/) above the syllable is used to indicate stress. In Part $B$ the stirllis is the voice. The response is the vocal reproduction of the correct number of syllables and the stress pattern.

Stage IV duplicates Stage III except the stin.dlus cards are eliminated.

Stage $V$ requires the sane auditory discrinination as Stage IV but is incorporated into sentences. Cards are again used as visial cues and stressed syllables are indicated, as before, by slash narks.

In. Stage VI the slash narks are eliminated.

In Stage VII the child faces the teacher as sentences are presented to him. No cards are used as visual cues. The response required is the repetition of the sentence with the appropriate stress.

Rationale

In all stages of the program, the emphasis is on loudness instead of pitch or duration, because in working with children it has been observed that a higher pitch and longer duration usually accompany an in rease in loudness. Zemlin (1968) explained the pitch change as follows:

The increase of pitch that usually accompany increases in intensity (loudness) of phonation can be accounted for by the greater tension of the vocal folds.

He said that the increased glottic tension was brought about by the contraction of the thyroarytenoid muscles and/or the cricothyroid. It is felt that the auditory stimulus, particularly the voice, 
CHAPIER IV

A PROGRA. TO TEACH ANARHESS OF JTRESS

$$
\begin{aligned}
& \text { Stage I } \\
& \text { Part A }
\end{aligned}
$$

\section{Descriotion of stace:}

Part $A$ is the identification of sound presence and counting the number of syllables present.

Behavioral objectives:

The child can identify the number of beats heard by pointing to the correct card 90 percent of the time.

The child can identify sound presence by pointing to the appropriate card gn percent, of the tine.

Demonstration of task:

Place two cards on table in front of child. One card should be blank and one card should have a large " $\mathrm{X}$ " on it. Touch child on shoulder imrediately following each stimulus as a signal for response.

$$
\text { Stimulus }
$$

1. Face child, strike drum once.

2. Face child, do not strike drum.

3. Have child close eyes, strike drum once.

4. Have child close
- Teacher Response

1. Pointing to " $X$ " card.

2. Pointing to blank card.

3. Pointing to "X" card.

4. Pointing to blank card. 
eyes, do not strike

drum.

Repeat steps 3 and 4 three tines, helping child point to correct card.

Task I

Instractions for task:

The lank card and the card with the "X" are placed in front of the child. Give the following directions:

I Nant yo: to listen for the irin. If I do tot strike it point to the blank card (point to card) it en I toich your shoulder. If I strike it, point to the card with the "X" (point to card) when I touch your shoulder.

$$
\text { jtinilis }
$$

Child teanonse

Have child close eyes, randor choice of striking or not striking the drum.

Pointing to correct card following signal for response.

Pass criteria: Go to Task II.

Fail criteria: Go to Branching Task I.

Task II

Additional materials: Card with two " $\mathrm{X}$ "S printed on it. Instructions for task:

Repeat instructions for Task I with the addition of:

If I strike it two tiies, point to the card with the two

"X"s '(point to card) when I touch your shoulder.

Stimulus

Have child close eyes, randor choice of not strikin the drum or striking it one or two tines.
Child Response

Pointing to correct card following signal for response. 
Pass criteria: Go to Task III.

Fail criteria: Go to Branching $\mathrm{T}_{\mathrm{a}} \mathrm{sk}$ II.

Task III

Additional materials: Card with three "X"s.

Instructions for task:

Repeat instructions for Task I with the addition of:

If I strike it two times, point to the card with the two "X"s on it (point to card) when I touch your shoulder. If I strike it three times, point to the card with the three "X"s on it (point to card) when I touch your shoulder.

Stimulus

Have child close eyes, random choice of striking the drum one, two or three times or not striking it.

Pass criteria: Go to task IV.

Fail creteria: go to Branching task III.

Task IV

Additional materials: Card with four "X"s. Instructions for task:

Repeat instructions for Task I with the addition of:

If I strike it two times, point to the card with two "X"s

on it (point to card) when I touch your shoulder. If I strike it three times, point to the card with three "X"s on it when I touch your shoulder. If I strike it four times, point to the card with the four"X"s on 1 when I touch your shoulder.

Stimulus

Have the child close eyes, random choice of wut striking
Child Response

Pointing to the correct card following signal for response. 


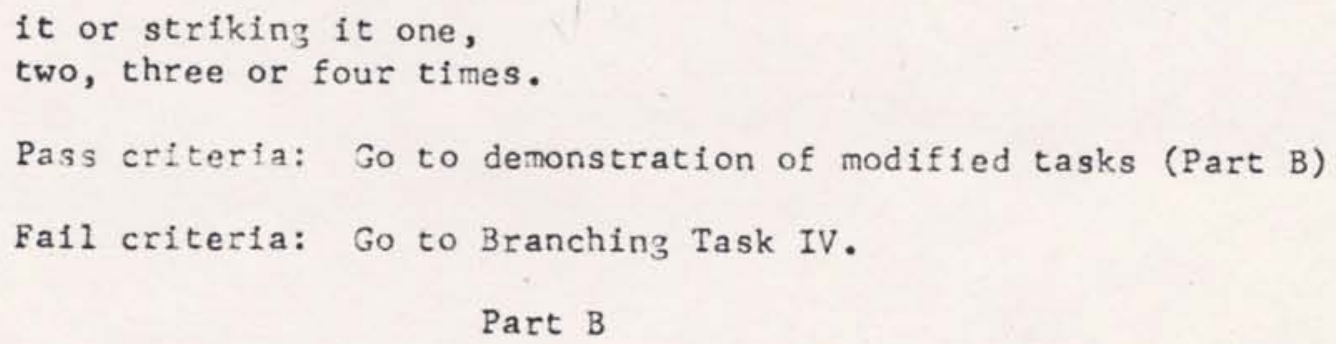

\section{Description of stage:}

Part $B$ involves the repetition of a syllable pattern as the child's response.

Behavioral objectives:

The child can repeat the syllable pattern heard 90 percent of the time.

Child can identify the number of beats heard by pointing to the correct card 90 percent of the time.

Demonstration of the task:

Place two cards on table in front of child. One carc should be blank and one card should have the syllable (bM). Touch the child on the shoulder immediately following each stimulus as a signal for response.

Stimulus

1. Face the child, strike drum once.

2. Face child, do not strike drum.

3. Have child close eyes, strike drum once.

4. Have child close eyes, dó not strike drum.
Teacher Response

1. Point to card and say the syllable.

2. Point to blank card, do not say anything.

3. Point to card, say the syllable.

4. Point to blank card, do not say anything.

Repeat steps 3 and 4 three times, helping the child to point to correct card. 
rask I

Materials: One blank card and one card with a large "X" on it. Instructions:

The blank card and the card with the "X" are placed in front of the child. Give the following directions:

I want you to listen for the drum. If I do not strike it, point to the blank card (point to the card) when I touch your shoulder and do not say anything. If I strike it one time, point to the card with the "X" on it (point to card) when I touch your shoulder.

\section{Stimulus}

Have child close eyes, random choice of striking or not striking the drum.
Child Response Pointing to correct card following signal for response, verbalization of the syllable if the drum is struk.

Pass criteria: Go to Task II.

Fail criteria: Go to Branching Task V.

Task II

Additional mateials: Card with two "X"s.

Instructions:

Repeat instructions for TaskI with the addition of:

If I strike it two times, point to the card with the two "X"s (point to card) and say $(b \Lambda)$ two times.

\section{Stimulus}

Have child close eyes, random choice of not striking the drum or striking it one or two times. Pass criteria: Go to Task III
Child Response

Pointing to correct card following signal for response, verbalization of the syllable depending on stimulus. 
Fall criteria: Go to Branching Task VII.

Task IV

Additional materials: Card with three "X"s.

Instructions:

Repeat instructions for Task I with the addition of:

If I strike it two times, point to the card with the two"X"s (point to card) and say (b $\Lambda)$ two times. If I strike it three times, point to the card with the three "X"s (point to card) and say (b^) three times.

Stimulus

Child Response

Have child close eyes, random Pointing to correct card choice of striking or not striking following signal for response, the drum. verbalization of $(b /)$ one, two or three times depending on stimulus.

Pass criteria: Go to Stage II.

Fail criteria: Go to Branchin; Task VIII.

Branching Task I

Materials: One blank card,one with an"X" and a drum.

Stimulus

1. Face child, put child's hand on drum, strike drum once.

2. Face child, do not strike drum, child's hand is on drum.

3. Have child close eyes, put child's hand on drum, strike it once.

4. Have child cloe eyes, put child's hand on drum, do
Child Response

1. Pointing to " $X$ " card following signal for response.

2. Pointing to blank card following signal for response.

3. Pointing to "X" card following signal for response.

4. Pointing to blank card following signal for 
not strike dr $\lambda$. $\quad$ response.

Repeat steps 3 and 4 randorly ten times with child responding

by himself.

Go vack to Task I.

Branching Task II

Materials: One blank card, one with two "X"s, and a drum.

Stimulus

1. Face child, put child's

hand on drum, strike

drun two tines.

2. Face crild, put crild's

hand on indr, to not

strike ir im.

3. Have cilild close eves, put crild's hand on irum, strike drun two tires.

4. Have child ciose eyes, put child's hand on drum, do not strike drum.
Child and Teacher Respons:

1. Pointing to correct card following sigral for response.

2. Poinuline to quake cini

following signal for response.

3. Poinutig to conrect card following signal for response.

4. Pointing to blank card following signal for response.

Repeat steps 3 and 4 randomly ten times with child responding by hinself.

Go back to Task II.

Task III

Naterials: One card with one "X", one with three "X"s and a drum.

Stimulus

1. Face child, put child's hand on drum, strike drum three tines.

2. Face child, put child's hand on drum, strike drum one tire.

3. Have child close eyes, put child's hand on drum, strike drum three times.
Child and Teacher Response

1. Pointing to correct card following signal for response.

2. Pointing to correct card following signal for response.

3. Pointing to correct card following signal for response. 


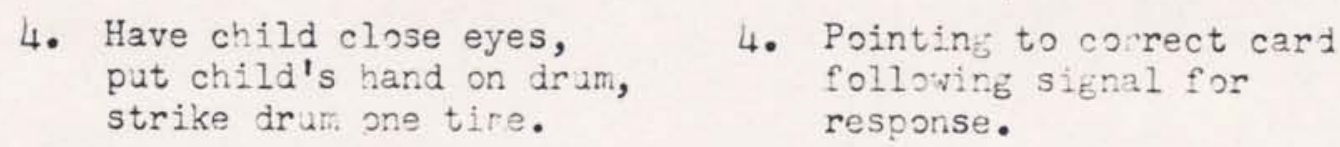

4. Pointing to correct card following signal for response.

Repeat steps 3 and 4 randorly $t$ n tires with child responding by

himself.

Go back to Task III

Branching Task IV

Naterials: One card with two "X"s, one with for "X"s and a drum. Stimulus

Child and Teache? tesponse

1. Face crild, put child's hand on drum, strike drum four times.

1. Pointing to correct card following signal for response.

2. Face child, put child's hard on drum, strike drum two tires.

2. Pointing to correct card following signal for response.

3. Have child close eyes, put cnild's hand on drum, strike drum four tines.

3. Pointing to correct card following signal tor response.

4. Have child close eyes, put child's hand on drum, strike drum tivo tines.

4. Pointine to correct card following signal for response.

Repeat steps 3 and 4 randorily ten tires with child responding by hirself.

Go to Task IV.

Branching Task $\mathrm{V}$

Naterials: One blank card and one with an "X" on it.

Stimulus

1. Face child, put child's hand on drum, strike drum once.

2. Face child, put child's hand on drum, do not strike drum.
Child and Teacher Response

1. Pointing to " $\mathrm{X}$ " card following signal for response, say (bu) once.

2. Pointing to blank card following signal for response. 
3. Have child close eyes, put his hand on drum, strike dram once.

4. Have child close eyes, put his rand on arum, do not strike drum.
3. Pointing to " $X "$ card following signal for response, say $(b \wedge)$ once.

4. Pointing to blank card following signal for response.

Repeat steps 3 a d 4 randonly ten tines with child responding by

hi: self.

Go back to Task I, Part B.

Branching Task VI

Follow Branching Task II. Add child saying the syllable (bA) the

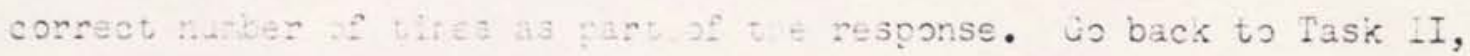
Part 3 .

Branchin: Task VII

Follow Branching Task III. Add crild saying tne syllaole (bA) the correct nimiver of tities as part of the response. Go back to

Task III, Part 3 .

Branching Task VIII

Follow Branching Task IV. Add child saying the syllable (b $\Lambda$ ) the correct number of times as part of the response. Go back to Task IV, Part B.

\section{Stage II}

Part A

\section{Description of stage:}

Part A involves the identification of sound presence and counting the number of syllables present.

Part B deals with the repetition of syllable patterns. Behavioral objectives: 
Part A

Child can identify the number of beats heard by pointing to the correct card 90 percent of the tire.

Child can identify sound presence by pointing to the correct card 90 percent of the time.

Part B

Child can repeat the syllable patte $n 90$ percent of the time.

Child can identify the number of beats heard by pointing to the correct card 90 percent of the time.

\section{Instriptions:}

Follow the procedure for Stage I but substitute saying the syllable $\left(b_{\Lambda}\right)$ for the drum. In the brancning tasiks instead of putting the cnild's hard on the irdr put it on t:e teacher's trroat.

Stage III

Part A

\section{Description of stage:}

Part A involves the identification of differences in intensity of sounds. It requires the child to identify stress patterns. It also counts the number of syliables present.

Behavioral objectives:

Child can identify the number of beats heard by pointing to the appropriate card and imitating what he heard 90 percent of the time.

Child can identify the appropriate stress pattern by pointing to the appropriate card and initating what he heard 90 percent of the tine. 
Place two cards on the table in front of the child. One card should have $\left(b_{\Lambda} b / \Lambda\right)$, and the other should have $\left(b_{\Lambda}\right)$ printed on it. Touch child on shoulder in rediately following each stinulus as signal for response.

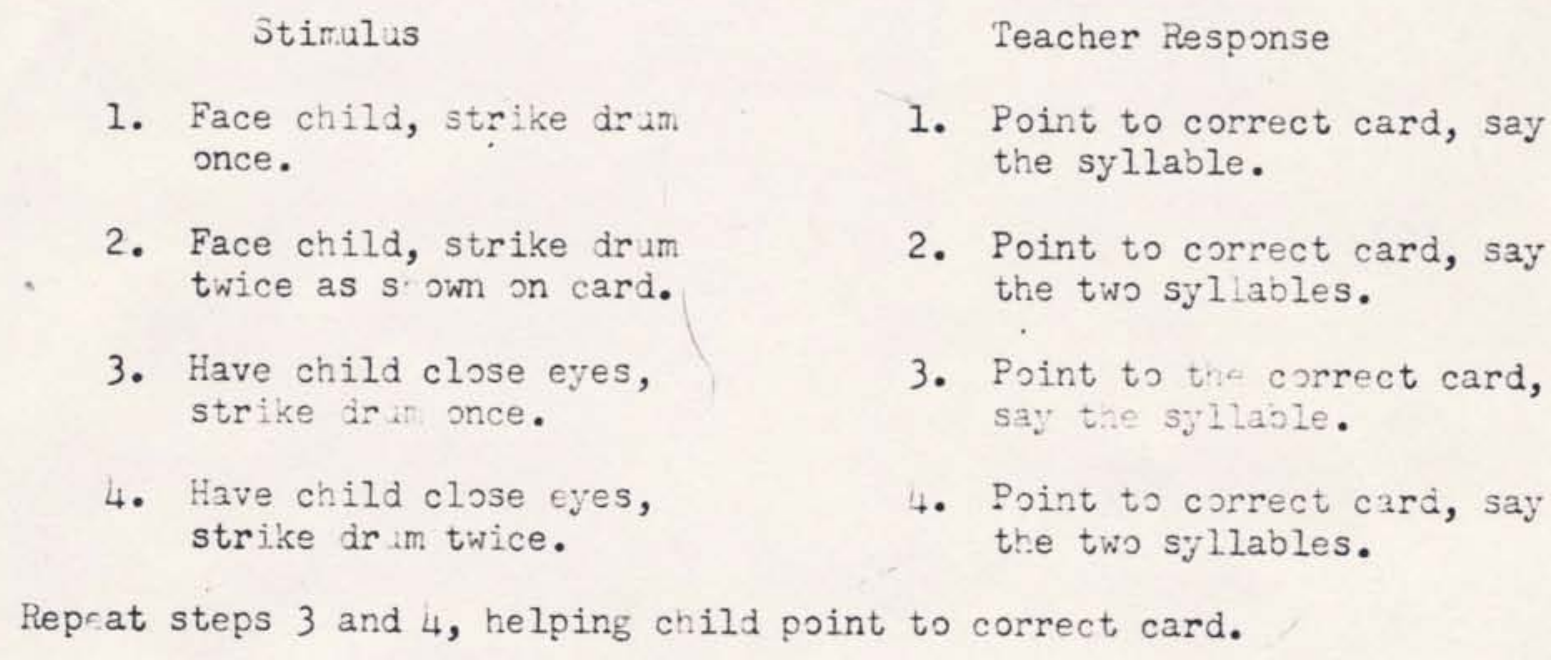

Task I

Instructions for Task:

The cards ased in the demonstration task are placed in front of the child. Give the following directions:

I want you to listen for the drum. Some of the beats will be louder than others. If it is louder there will be a slash mark above the syllable. If I strike the drum one tire, point to the card with one syllable (point.to card) when I touch your shoulder. Then say the syllable the same way you heard it. If I strike it two times, point to the card with two syllables (point to card). Then say the syllables the same way you heard them. Remember some will be louder.

Stimulus

Have child close eyes, random
Child Response Pointing to correct card fol- 
choice of striking the drum once or twice following stress patterns rarked on cards.
Pointing to correct card following signal for response and saying the syllable once or twice following stress pattern on card.

Pass criteria: Go to Task II.

Fail criteria: Go to Branching Task I.

Task II

Additional naterials: Card with three syllables on it $(b \wedge b \wedge b \wedge)$.

Instructions:

Repeat instructions for Task I with the addition of:

If I strike it two tires, point to tre card with the two

syllables (point to card). Then say then the sare way : od

heari ther. If I strike it three tines, point to the cand with

three syllables (point to card) and say the syllables the sare way yos noard then.

Stimulus

Have child close eyes, random choice of striking the irum. one, two, three tires, following the stress patterns marked on cards.
Child Response

Pointing to correct card following signal for response and saying the syllables the correct nunber of tires, following the stress pattern on the card

Pass criteria: Go to Task III.

Fail criteria: Go to Branching Task II.

Task III

Additional materials: Card with four syllables $(\mathrm{b} / \mathrm{b} \Lambda \mathrm{b} / \mathrm{b} \Lambda)$. Instructions :

Repeat instructions for Task I with the addition of:

If I strike it two times,point to the card with the two syllables (point to card). If I strike it. three times, point to the card with the three syllables (point to card). then say the syllables the saie way you heard them, If I strike it 
four tires, point to tne card with four syllables (point to card) and then say trem the sare way you heard them.

$$
\text { Stimulus Child Response }
$$

Have child close eyes, randon cnoice of striking

Pointing to correct card the drum one, two, three following signal for response or four tires following tre stress patterns on cards. and saying syllables the correct number of tires following the stress pattern on card.

Pass criteria: Go to Part B

Fail criteria: Go to Brancning lask III.

Part B

\section{Description of stage:}

This part of the stage involves the repetition of the syllable pattern and of the stress pattern.

Behavioral obiectives:

Child can vocally reproduce the correct nurber of syllables 90 percent of t:e time.

Child can vocally reproduce the appropriate stress pattern 90 percent of the tine.

\section{Demonstration of the task:}

Place two cards on the table in front of the child. One card should have two syllables $(b \wedge b h)$ and one card should have one syllable $(b \Lambda)$ printed on it. Touch child immediately on shoulder to sijnal for a response.

Stimulus

1. Face child, say syllable once as shown on card.
Child Response

1. Point to card with $\left(b_{\Lambda}\right)$, say $\left(b_{\Lambda}\right)$. 


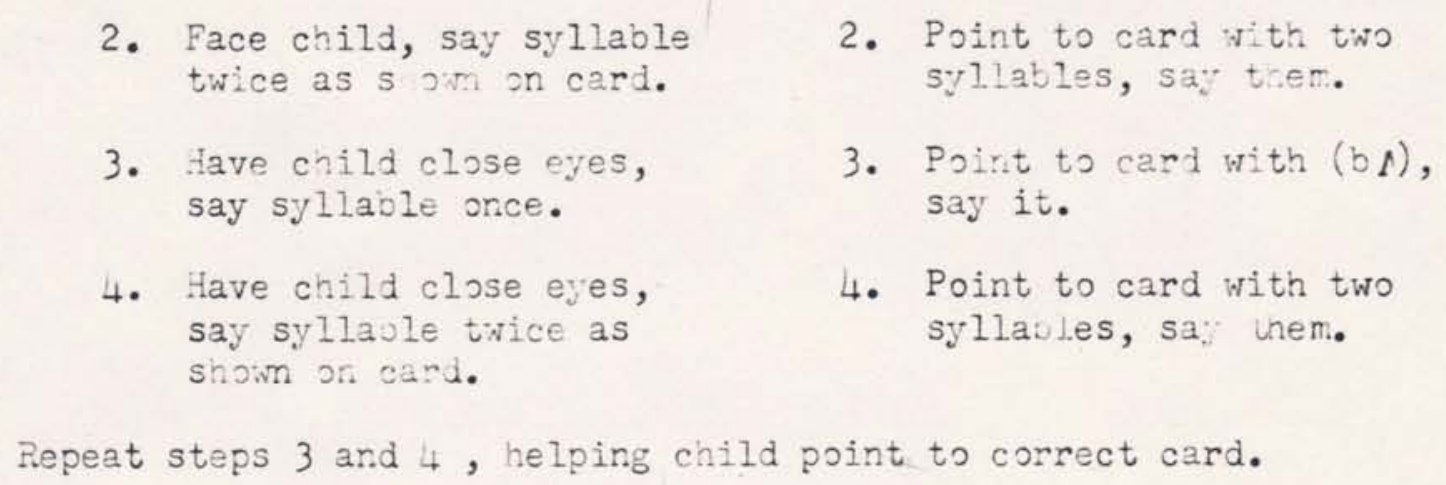

Repeat steps 3 and 4 , helping child point to correct card.

Task I

Instructions for task:

The cards ised in the deronstration task are placed in front of the child. Give the following directions:

I want you to listen to ny voice. Sore of the syllables will be louder than others. If it is louder there will be a slash rark above the syllable. If I say ( $b \wedge$ ) point to the card with one syllable (point to card) when I touch your shoulder. Then say the syl able the sare way you heard it. If I say it two tires, point to the card with two syllables (point to card). Then say them the sare way you heard them.

\section{Stinulus}

Have child close eyes, random choice of saying the syllable once or twice following stress patterns as marked on cards.

\section{Child Response}

Pointing to correct card following signal for response and saying the syllable once or twice following stress patterns on cards.

Pass criteria: Go to Task II.

Fail criteria: Go to Branching Task IV.

Task II

Additional raterials: Card with three syllables (bMb/b $\Lambda)$. Instrictions for task: 
Repeat instructions for Task I with the addition of:

If I say the syllable two tires, point to the card with two syllables (point to card) and then say them the same way you heard them. If I say the syllable three tires,point to the card with the three syllables (point to card). Then say ther. the sa:e wy you heard them.

$$
\text { Stin.ulis }
$$

Have child close eyes, randon. choice of sayin, the syllable one, two or thr e tines following stress patterns narked on cards.

\section{Child Response}

Pointing to correct card following sional for response and saying the syllatole the correct nuber of times following the stress pattern on the curd.

Pass criteria: Go to Task III.

Fail criteria: Go to Branching Task V.

Task III

Additional rate ials: Card with four syllables on it (bíbnb ́́b $\mathrm{b}$ ). Instractions for task:

Repeat instructions for Task I with the additions of:

If I say the syllable two tines, point to the card with the two syllables (point to card). Then say them the sare way yos heard them. If I say them three tires, point to the card with three syllables (point to card) and say then the sane way you heard them. If I say them four tines, point to the card with four syllables (point to card) and say then the sare way you heard them.

\section{Stimulus}

Have child close eyes, random choice of saying the syllable one, tivo, three or four times following the stress pattorns
Child Response

Pointing to correct card following signal for response and saying the syllables the correct number of tires following the stress pattern on the card. 
marked on cards.

Pass criteria: Go to Stage IV.

Fail criteria: Go to Branching Task VI.

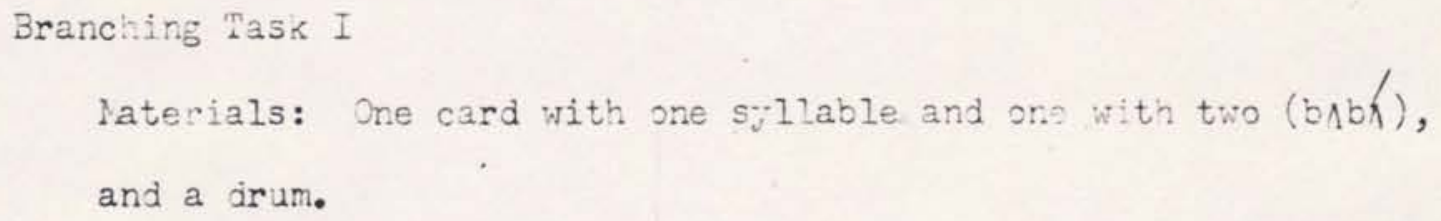

1. Face child, put child's hand on drum, strike drun. once.

2. Face cuild, pit crili:'s hand on ir in, strike in tim twice following stress pattern on card.

3. Kave cilla close eyes, put crild's hand on drum, strike drum once.

4. Have child close eyes, put child's hand on drum, strike drun twice.
1. Pointing to conr ct card following sisnal for a spo.tse, saying syllable once.

2. Dointire to comect card Eollowing signal for $r$ spouse, saying syllables as stress pattern indicates.

3. Pointin to couroot cand following signal for response, saying syllable once.

4. Pointing to correct card following signal for response, sayin syllables as the stress pattern on card indicates.

Repeat steps 3 and 4 randomily ten times with child responding by himself.

Go back to Task I, Part A.

Branching Task II

Materials: Card with one syllable, card with three syllables $(\mathrm{b} \wedge \mathrm{b} / \mathrm{b} \Lambda)$, drum.

Stimilus

Child and Teacher Response

1. Face child, put child's hand on drum, strike drum once.

1. Pointing to the correct card following signal for response saying syllable once.

2. Face child, put child's

2. Pointing to correct card fol- 
hand on drum, strike drun three tires following stress pattern on card.

3. Have cnild close eyes, put child's hand on drum, strike drum once.

4. Have child close eyes, put child's hand on drum, strike ir in: three tires following stress pattern on card. lowing signal for response, saying syllables as stress pattern indicates.

3. Pointing to correct card following signal for response, saying syllable once.

4. Pointing to correct card following sienal for response, saying syllaoles as the stress pattern indicates.

Repeat steps 3 and 4 randomly ten tires with child responding by hirself.

Go back to Task II. Eranching lask ili

Naterials: Card with two syllables (bnbh), card with four syllables

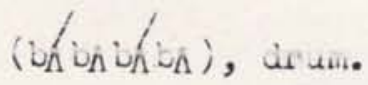

Stinulus

1. Face child, put child's hand on drum, strike drum twice.

2. Face child, put child's hand on drun, strike drum four tines following stress pattern on card.

3. Have child close eyes, put child's hand on drum, strike drum twice.

4. Have child close eyes, put child's hand on drum strike drum four times following stress pattern on card.
Child and Teacher Response

1. Pointing to correct card following signal for response, saying syllables as pattern shows.

2. Pointing to correct card following signal for response, saying syllables as stress pattern indicates.

3. Pointing to correct card following sicnal for response, saying syllables as pattern shows.

4. Pointing to correct card fold lowing signal for response, saying syllables as the stress pattern indicates.

Repeat steps 3 and 4 randomly ten times with child responding by himself. 
Go back to Task III.

Branching Task IV

Follow Branching Task I, changing stinulus to saying the syllables.

Child can place hand on teacher's tarpat. Go back to Task IV. Branching Task $V$

Follow procedure for 3rancning Task II, changing the stimulus

to sayin: the syllables. Child can place hand on teacher's

. throat. Go back to Task V.

Branciing Task VI

Follow Branching Task III. changing the stirulus to saying the syllables. Child can place hand on teacher's timroat. Go back to Task VI.

Stage IV

\section{Description of stage:}

Part $\mathrm{A}$ of this stage involves the counting of the number of syllables. It also involves the identification of differences in intensity of sounds and the identification of stress patterns. The stimulus is a drum.

In Part $B$ the child is required to repeat a syllable pattern and a stress pattern. The stimulus is the voice. Behavioral objectives:

Part A

Child can vocally reproduce the correct nut ber of syllables 90 percent of the time.

Child can vocally reproduce the appropriate stress pattern 90 percent of the time. 
Part B

Child can vocally reproduce the correct number of syllables 90 percent of the time.

Child can vocally reproduce the appropriate stress pattern

90 percent of the time.

Instructions:

Follow the same procedure used in Stage III but eliminate the cards.

$$
\begin{aligned}
& \text { Stage V } \\
& \text { Part A }
\end{aligned}
$$

Description of staje:

In this stage the same auditory discrimination is required but sentences are used rather than the syllable $(b \Lambda)$.

Behavioral objectives:

Child can point to the correct sentence 90 percent of the time. Child can vocally reproduce it 90 percent of the time.

Child can imitate the stress pattern of the sentence 90 percent of the time.

Demonstration of task:

Place two sentences written on cards on table in front of child. One card should have a one syllable sentence printed on it and one should have a two syllable sentence printed on it with a slash mark above the stressed syllable. 
Stimulus

1. Face child, strike drum once.

2. Face child, strike drum twice as snown on card.

3. Have child close eyes, strike drut once.

4. Have child close eyes, strike ar in. twice as siown on card.

\section{Teacher Response}

1. Point to card with one syllable sentence, say it.

2. Point to card with two syllable sentence, say it as suown on card.

3. Point to card with one syllable, say it.

4. Point to card with two syllable sentence, say it with appropriate stress.

Kepeat steps 3 and 4 , helping child to point to correct card.

\section{Task I}

Instructions for task:

The cards with the two sentences are placed in front of the child. Give ine following directions:

I want yoi to listen for the drum. Jore of the beats will ice louder than the others. If it is louder there will be a slash nark above the syllable. If I strike the drum one tire, point to the card with one syllable (point to card) when I touch your shoulder. Ihen say it the sare way you heard it. If I strike it two tires, point to the card with the two syllable sentence (point to card). Then say it the same way you heard it.

$$
\text { Stimulus }
$$

Have child close eyes, random chioce of striking the drum once or twice following the stress pattern narked on card.
Child Response

Pointing to correct card following signal for response and saying the sentence following the stress pattern on card.

Pass criteria: Go to Task II.

Fail criteria: Go to Branching Task I. 
Task II

Additional naterials: Card with three syllable sentence.

Instractions for task:

Repeat instrictions for Task I with the addition of:

If I strike the drum three times, point to the card with the three syllable sentence (point to card) when I touch your shoxlder. Then say it the sase way you heard it.

Stir.ilus

Have child close eyes, randor choice of striking the drum, one, two on tinre tiries.
Child Response

Pass criteria: Go to Task III.

Fail criteria: Go to Branching Task II.

\section{Task III}

Additional raterials: Card with for syllable sentence. Instructions for task:

Repeat instructions for Task I with the addition of:

If I strike it three times, point to the card with the three syllable sontence (point to card). Then say the sentence the sare way yoi heard it. If I strike the drum four tires, point to the card wit. the foir syilable sentence (point to card). Then say the sentence the saite way you heard it.

\section{Stimilus}

Have child close eyes, random choice of striking the drum. one, two, three or four times following stress patterns on cards.

Bass criteria: Go to Task IV.

\section{Z:A Child Response}

Pointing to correct card following signal for response and saying the sentences following the stress pattem on the card.

Fail criteria: Go to Branching Task III. 
Part B

Description of stage:

In part $B$ the stimulus changes from a drumbeat to voice but the response required from the child is the same.

Behavioral objectives:

Child can point to the correct sentence 90 percent of the time. Child can vocally reproduce the sentence 90 percent of the time.

Child can imitate the stress pattern of the sentence 90 percent of the time.

Demonstration of task:

Place two sentences on table in front of child. One card should have a one syllable sentence printed on it and one should have a two syilabie sentence on ic wich a siash mark above lie stressed syilabie.

Stimulus

1. Face child, say one syllable sentence.

2. Face child, say two syllable sentence.

3. Have child close eyes, say one syllable sentence.

4. Have child close eyes, say two syllable sentence.
Teacher Response

1. Pointing to correct sentence, saying it.

2. Pointing to correct sentence, saying it.

3. Pointing to correct sentence, saying it.

4. Pointing to correct sentence, saying it.

Repeat steps 3 and 4 , helping child point to the correct card.

\section{Task I}

Instruction for task:

The cards with the two sentences are placed in front of the child. Give the following directions: 
I want you to listen. Some of the syllables will be louder than others. If it is louder there will be a slash mark above the syllable. If I say the one syllable sentence, point to the card with it (point to card). Then say it as you heard it. If I say the two syllable sentence, point to the card with that sentence on it (point to card) when I touch your shoulder. Then say it as you heard it.

\section{Stimulus}

Have child close eyes, random choice of sayinz one or two syllable sentence following the stress pattern marked on the carcs.

\section{Child Response}

Pointing to correct card following signal for response and saying the sentence following the stress pattern on the card.

Pass criteria: Jo to Zask II, Part 3 .

Fail criteria: Go to Branching Task IV.

Task II

Additional materials: Card with three syllable sentence.

Instruction for task:

Repeat instructions for Task IV with the addition of:

If I say the three syllable sentence, point to the card with the three syllable sentence (point to card). Then say the sentence the same way you heard it.

\section{Stimulus}

Have child close eyes, random choice of saying one, two or three syllable sentence following the stress patterns marked on cards.
Child Response Pointing to correct card following signal for response and saying the sentence following the stress patterns on cards.

Pass criteria: Go to Task III, Part B.

Fail criteria: Go to Branching Task V. 
Task III

Additional materials: Card with four syllable: sentence. Instructions for task:

Repeat instructions for Task $V$ with the addition of:

If I say the three syllable sentence, point to the card with that sentence (point to card). The say it the same way you heard it. If I say the four syllable sentence, point to that sentence (point to card). Then say the sentence the same way you heard it.

Stimulus

Have child close eyes, random choice of one, two, three or four syllable sentence followin? the stress patterns tharked on the cards.
Child Response

Pointing to correct sentence following signal for response, saying the sentence following the stress patterns marked on the cards.

Pass criteria: Go to Stage VI.

Fail criteria: Go to Branching Task VI.

Branching Tasks

Follow the Branching Tasks for Stage III substituting the sentences for the syllables.

\section{Stage VI}

\section{Description of stage:}

Part A

In the first part of this stage it requires the identification of differences in intensity of sounds and the identification of stress patterns. It also requires the identification of sentences. Part B

Part B involves the repetition of sentences and stress patterns. The stress patterns are not marked on the cards. 
Behavioral objectives:

Child can point to correct sentence 90 percent of the time. Child can vocally reproduce it 90 percent of the time.

Child can imitate the stress pattern of the sentence 90 percent of the time.

\section{Instructions:}

Follow the same procedure as Stage $V$ but eliminate the stress patterns on the cards.

\section{Description of the stage:}

\section{Stage VII}

In this stage the child can watch the teacher. It involves the imitation of sentences, randomly chosen, and of stress patterns. The sentences are not presented on cards.

Behavioral objectives:

Child can repeat sentences presented to him using the correct stress patterns 90 percent of the time.

Child can repeat sentences of more than four syllables with the appropriate stress pattern 90 percent of the time.

\section{Instructions:}

I want you to listen. I am going to say a sentence and then I want you to say it the same way.

Task I

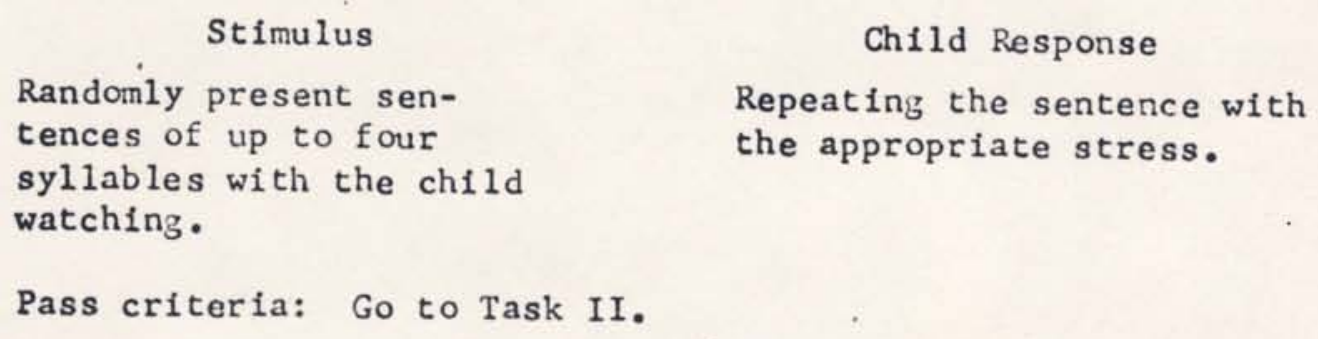

Child Response Repeating the sentence with the appropriate stress. 
Fail criteria: Go to Branching Task I.

Task II

Instructions :

I am going to say a sentence. I want you to listen and then. say it the same way.

\section{Stimulus}

Present sentences, gradually increase the number of syllables.

Pass criteria: Conclude program

Fail criteria: Go to Branching Task II.
Child Responses Repeating the sentence with the appropriate stress.

Branching Task I

Follow Task I but add visual cues of the sentences written on cards and placed in front of the child on a table.

Branching Task II

Follow Task II but use visual cues in the form of sentences written on cards which are placed on a table in front of the child. 
CHAPTER V

\section{SUMMARY}

Stress, as previously discussed in Chapter II, is felt to be of great importance in carrying meaning. A hearing impaired child needs to be aware of stress and needs to know what to do to produce it in his own speech.

The program has been revised greatly from the original. It is desizned to eliminate some of the traditional steps, such as, first teaching intensity and then tenching pitch changes. It is hoped that stress can be taught more quickly and simply by presenting it as a listening tack combined with vortal responses.

The use of equipment has been kept to a minimum to make the program easy to implement. The materials are teacher-made and can be laminated for more durability. The hearing aid or aids used must be in excellent working order to get maximum benefit from the program.

The program as written may not work for all children, but might need to be adapted to fit the needs of individual children. This can be done easily by changing the materials slightly. For example, color coding could be used for stressed syllables. The manner of presentation could be changed to make the program more beneficial for the child. This could be done by having the children clap their hands instead of using a drum or by touching the child on the arm to indicate stress. The program is meant to be a guide and not an inflexible technique. 


\section{BIBLIOGRAPHY}

Aurbach, Joseph, Philip H. Cook, Robert B. Kaplan and Virginia Tufte. Transformational Gramar: A Guide for Teachers, Washington: Educational Associates, Inc., 164-165, (1969).

Boothroyd, Arthur. "Acoustics of Speech," Speech for the Deaf Child: Knowledze and Use, Leo E. Connor, ed., Washington, D. C.: Alexander Graham Bell Association for the Deaf, 3-44 (1971).

Brick, Sister Rose Marie. "Eurhythmics: One Aspect of Audition," Volta Review, Vol. 75, No. 3, 155-160 (March 1973).

Birkenshaw, Louis. "A Suggested Programme for Using Music in Teaching Deaf Children," Proceedings of International Conference on Oral Education of the Deaf, Vol. II, Alexander Graham Bell Association for the Deaf, Inc. 1233-1244, (1967).

Calvert, Donald."Speech Sound Duration and the Surd-Sonat Error," Volta Review, Vol 64, No. 7, 401-402 (Sept. 1962).

Geary, Catherine, et al. Sneech Develoment for the Deaf Child, New York: Doard of Education (1959).

Hudgins, C. V. and F. C. Numbers. "An Investigation of the Speech of the Deaf," Genetic Psychology Monograpis, The Journal Press (1942).

Jones, Carolyn. Deaf Voice, A Description Derived from a Survey of the Literature, Volta Review, Vol. 69, 507-508, 539-540 (1967).

Kurath, Hans. A Phonolozy and Prosody of Modern English, Ann Arbor: University of Michigan Press, 126 (1964).

Lehman, Jean Utley. "Linguistic Organization," Speech for the Deaf Child: Knowledge and Use, Leo E. Connor, ed., Washington D.C.: Alexander Graham Bel1 Association, 45-57 (1971).

Lorenz, Sister Mary Laurentine, "A Speech Progran for Deaf Children from 10 to 15," Proceedings of International Conference on Oral Education of the Deaf, Vol. I, Alexander Graham Bell Association for the Deaf, Inc., 652-663, (1967).

Magner, Marjorie E. "Techniques of Teaching," Speech for the Deaf Child: Knowledge and Use, Leo E. Connor, Ed., Washington $\frac{D_{0}}{C_{0}:}$ Alexander Graham Bell Association for the Deaf, 245-261, (1971). 
Martin, Sylvian. Speech Training for the Deaf Child, New York: W. W. Norton and Co., Inc., 53-54 (1941).

Moultin, Wm. G. A Linguistic Guide to Language Learning, Second Edition Manasha:George Banta Co., Inc., (1970).

Pike, Kenneth L. The Intonation of American English, Ann Arbor: The University of Michigan Press (1945).

Simmons, Audrey A. "Language and Hearing," Speech for the Deaf Child, Leo E. Connor, Ed., Washington, D. C.: Alexander Graham Bell Association for the Deaf, Inc. (1971).

Simmons-Martin, Audrey. "The Oral/Aural Procedures: Theoretical Basis and Rationale," Volta Review, Vol. 74, No. 9, 541-551 (Dec. 1972).

Tash, Marcia Faier. "Maintaining and Building Upon the Basic Foundations of Speech," Proceeding of the 46 th Meeting of the Convention of American Instructors of the Deaf, Washington D.C.: U. S. Gov't. Printing Office, 559-607 (1974).

Thomas, Charles. Phonetics of American English, New York: Ronald Press Co., 109-114 (1947).

Willemain, Thonas an! Francis F. Lee. "Tactile Pitch Feedback for Deaf Speakers," Volta Revier, Vol. 73, No. 9, 5i1-553, (Dec. 1971).

Woodward, Helen. "Intonation and the Teaching of Speech," Proceedings of International Conference on Oral Education of the Deaf, Alexander Graham Bell Association for the Deaf, Inc., 886-907 (1967).

Zemlin, Willard. Speech and Hearing Science: Anatomy and Physiolozy, Englewood Cliffs: Prentice-Ha11, Inc., $198-204(1968)$. 